\title{
PENGGEROMBOLAN PERUSAHAAN DALAM INDEKS LQ45 DENGAN MENGGUNAKAN ANALISIS GEROMBOL HIBRID
}

\author{
RAHYU SILVIA, MAIYASTRI, HAZMIRA YOZZA \\ Program Studi Matematika, \\ Fakultas Matematika dan Ilmu Pengetahuan Alam, Universitas Andalas, \\ Kampus UNAND Limau Manis Padang, Indonesia, \\ email : rahyusilvia@gmail.com
}

\begin{abstract}
Abstrak. Salah satu analisis yang dapat dilakukan pada perusahaan yaitu melalui analisis laporan keuangan berdasarkan komponen-komponen data keuangan. Dari analisis tersebut dapat dikelompokkan perusahaan yang bercirikan komponen data keuangan yang baik, dan perusahaan yang bercirikan komponen data keuangan yang kurang baik. Pada paper kali ini akan dianalisis laporan data keuangan dari perusahaan-perusahaan yang berasal dari kelompok perusahaan indeks LQ45 periode data keuangan Juni 2016. Perusahaaan tersebut dikelompokkan kedalam beberapa kelompok berdasarkan peubahpeubah yang terdapat pada data keuangan. Teknik statistika yang digunakan untuk penggerombolan perusahaan tersebut adalah analisis gerombol hibrid, yang merupakan gabungan dari metode gerombol tak berhirarki dan berhirarki. Berdasarkan hasil analisis gerombol hibrid ini, diperoleh dua gerombol, yang mana gerombol I terdiri atas 35 perusahaan dengan ciri komponen data keuangan yang relatif sedang dan gerombol II terdiri atas enam perusahaan dengan ciri komponen data keuangan yang relatif tinggi.
\end{abstract}

Kata Kunci: Analisis gerombol hibrid, data keuangan, perusahaan

\section{PENDAHULUAN}

Semakin banyak perusahaan-perusahaan yang berdiri di Indonesia, menuntut setiap perusahaan untuk dapat mengolah dan menampilkan yang terbaik dalam kinerja perusahaan, ditunjang dengan strategi yang matang dalam segala segi termasuk dalam menganalisis laporan keuangan. Melalui analisis laporan keuangan, dapat diketahui posisi keuangan, kinerja keuangan dan kekuatan keuangan yang dimiliki perusahaan.

Sehubungan dengan hal itu,pada paper ini akan dianalisis perusahaanperusahaan yang berasal dari kelompok perusahaan indeks LQ45 yang terdaftar di Bursa Efek Indonesia (BEI) tahun 2016. Perusahaan-perusahaan itu terlebih dahulu dikelompokkan kedalam beberapa kelompok berdasarkan komponen data keuangannya, yang mana di dalam satu kelompok memiliki karakteristik yang mirip, sedangkan antar kelompok yang satu dengan kelompok yang lainnya memiliki karakteristik yang berbeda.

Teknik statistika yang dapat digunakan untuk menggerombolkan perusahaanperusahaan tersebut adalah analisis gerombol hibrid, yang merupakan gabungan dari metode gerombol tak berhirarki dan berhirarki. 


\section{KAJIAN PUSTAKA}

\subsection{Indeks $L Q 45$}

Indeks LQ45 adalah salah satu indikator indeks pasar saham Indonesia, dimana notasi LQ45 menyatakan suatu forum yang didalamnya berisi 45 perusahaan yang sahamnya memiliki tingkat likuiditas dan kapitalisasi pasar yang tinggi. Pada paper ini data yang digunakan adalah data laporan keuangan dari kelompok perusahaan Indeks LQ45 periode Juni 2016.

\subsection{Laporan Keuangan}

Laporan keuangan merupakan laporan tertulis yang memberikan informasi kuantitatif tentang posisi keuangan dan perubahan-perubahannya, serta hasil yang dicapai selama periode tertentu. Laporan keuangan bertujuan untuk menyediakan informasi keuangan mengenai suatu perusahaan kepada pihak-pihak yang berkepentingan sebagai pertimbangan dalam pembuatan keputusan-keputusan ekonomi. Laporan keuangan terdiri dari beberapa komponen penyusun.

Berikut ini akan dibahas definisi dari beberapa komponen penyusun laporan data keuangan tersebut.

\subsubsection{Asset}

Asset atau aktiva adalah hak-hak dan harta-harta yang merupakan sumber penghasilan yang dapat memberikan hasil pada masa sekarang dan pada masa yang akan datang, atau dengan kata lain adalah segala harta-harta yang dimiliki pada saat ini.

\subsubsection{Hutang}

Hutang dapat diartikan sebagai kewajiban yang harus dipenuhi untuk menyerahkan kas, barang, atau jasa dalam jumlah yang relatif pasti, pada masa yang akan datang dengan periode yang relatif pasti, sebagai ganti atas manfaat atau jasa yang diterima oleh perusahaan pada masa yang lalu.

\subsubsection{Modal}

Modal adalah segala nilai yang dimiliki oleh perusahaan dan digunakan untuk mendapatkan pendapatan.

\subsubsection{Pendapatan}

Pendapatan merupakan jumlah uang yang diterima oleh perusahaan dari aktivitasnya, kebanyakan dari penjualan produk dan/atau jasa kepada pelanggan.

\subsection{5. $L a b a$}

Pengertian laba secara umum adalah selisih dari pendapatan di atas biaya-biayanya dalam jangka waktu (periode) tertentu. 


\subsubsection{Rasio Hutang terhadap Asset (Debt to Assets Ratio/DAR)}

Rasio hutang terhadap asset merupakan rasio yang digunakan untuk mengukur perbandingan antara total hutang dengan total asset. Dengan kata lain, rasio ini digunakan untuk mengukur seberapa besar asset perusahaan dibiayai oleh hutang atau seberapa besar hutang perusahaan berpengaruh terhadap pembiayaan asset. Berikut adalah rumus yang digunakan untuk menghitung DAR:

$$
\mathrm{DAR}=\frac{\text { Total Hutang }}{\text { Total Asset }}
$$

\subsubsection{Rasio Hutang terhadap Modal (Debt to Equity Ratio/DER)}

Rasio hutang terhadap modal merupakan rasio yang digunakan untuk mengukur besarnya proporsi hutang terhadap modal. Rasio ini dihitung sebagai hasil bagi antara total hutang dengan modal. Rasio ini berguna untuk mengetahui besarnya perbandingan antara jumlah dana yang disediakan oleh kreditur dengan jumlah dana yang berasal dari pemilik perusahaan. Berikut adalah rumus yang digunakan untuk menghitung DER:

$$
\mathrm{DER}=\frac{\text { Total Hutang }}{\text { Tota Modal }}
$$

\subsubsection{Hasil Pengembalian atas Asset (Return on Assets/ROA))}

Hasil Pengembalian atas asset merupakan rasio yang menunjukkan seberapa besar kontribusi asset dalam menciptakan laba bersih. Dengan kata lain, rasio ini digunakan untuk mengukur seberapa besar jumlah laba bersih yang akan dihasilkan dari setiap rupiah dana yang tertanam dalam total asset. Berikut adalah rumus yang digunakan untuk menghitung ROA:

$$
\mathrm{ROA}=\frac{\text { Laba bersih }}{\text { Total Asset }} \times 100 \%
$$

\subsubsection{Hasil Pengembalian atas Modal (Return on Equity/ROE)}

Hasil pengembalian atas modal merupakan rasio yang menunjukkan seberapa besar kontribusi modal dalam menciptakan laba bersih. Dengan kata lain, rasio ini digunakan untuk mengukur seberapa besar jumlah laba bersih yang akan dihasilkan dari setiap rupiah dana yang tertanam dalam total ekuitas. Berikut adalah rumus yang digunakan untuk menghitung ROE:

$$
\mathrm{ROE}=\frac{\text { Laba bersih }}{\text { Total Modal }} \times 100 \%
$$

\subsubsection{Marjin Laba Bersih (Net Profit Margin/NPM))}

Marjin laba bersih merupakan rasio yang digunakan untuk mengukur besarnya persentase laba bersih atas penjualan bersih. Berikut adalah rumus yang digunakan untuk menghitung ROE: 


$$
\mathrm{NPM}=\frac{\text { Laba bersih }}{\text { Penjualan bersih }} \times 100 \%
$$

\subsection{Analisis Komponen Utama (AKU)}

Analisis Komponen Utama merupakan suatu teknik statistika untuk mentransformasi peubah asal yang saling berkorelasi satu dengan yang lainnya menjadi satu set peubah baru yang lebih sedikit dan saling bebas (tidak berkorelasi lagi). Jadi Analisis Komponen Utama berguna untuk mereduksi data, sehingga lebih mudah untuk diinterpretasikan.

\subsubsection{Tahap-tahap Pembentukan Komponen Utama}

Jika $\mathbf{X}^{\prime}=\left(x_{1}, x_{2}, \cdots, x_{p}\right)$ merupakan vektor peubah acak, matriks ragam-peragam peubah acak $\mathbf{X}$ disebut $\operatorname{Var}(\mathbf{X})$ dilambangkan dengan $\sum$, dan dinyatakan sebagai:

$$
\begin{aligned}
\sum & =E\left[(\mathbf{X}-E(\mathbf{X}))\left[(\mathbf{X}-E(\mathbf{X})]^{\prime}\right]\right. \\
& =\left[\begin{array}{cccc}
\sigma_{11} & \sigma_{12} & \ldots & \sigma_{1 p} \\
\sigma_{21} & \sigma_{22} & \ldots & \sigma_{2 p} \\
\vdots & \vdots & \ddots & \vdots \\
\sigma_{p 1} & \sigma_{p 2} & \ldots & \sigma_{p p}
\end{array}\right]
\end{aligned}
$$

Dalam AKU, Komponen Utama ke-i adalah kombinasi linear dari peubah $X_{1}, X_{2}, \ldots, X_{p}$ dan dinyatakan sebagai

$$
Y_{i}=\mathbf{a}_{\mathbf{i}}^{\prime} \mathbf{X}
$$

Dengan demikian, maka

$$
\begin{aligned}
\operatorname{Var}\left(Y_{i}\right) & =\operatorname{Var}\left(\mathbf{a}_{\mathbf{i}}^{\prime} \mathbf{X}\right) \\
& =\mathbf{a}_{\mathbf{i}}^{\prime} \sum \mathbf{a}_{\mathbf{i}}
\end{aligned}
$$

Komponen utama $1, Y_{1}$, dibentuk dari kombinasi linier antara $X_{1}, X_{2}, \ldots, X_{p}$ sehingga keragaman $Y_{1}$ paling besar, atau $\operatorname{Var}\left(Y_{1}\right)=\mathbf{a}_{\mathbf{1}}^{\prime} \sum \mathbf{a}_{\mathbf{1}}$ terbesar. Dengan menggunakan fungsi Lagrange dimana kendala $\mathbf{a}_{1}^{\prime} \mathbf{a}_{1}=1$ maka dengan operasi matematika diperoleh $\operatorname{Var}\left(Y_{1}\right)=\mathbf{a}_{\mathbf{1}}^{\prime} \sum \mathbf{a}_{\mathbf{1}}=\lambda_{1}$. Dengan demikian $\operatorname{Var}\left(Y_{1}\right)$ maksimum maka $\lambda_{1}$ juga maksimum.

Komponen utama 2, $Y_{2}$, adalah kombinasi linier terbobot dari peubah asal yang tidak berkorelasi dengan komponen utama pertama serta memaksimumkan keragaman data yang belum diterangkan oleh komponen utama pertama. Dengan menggunakan fungsi Lagrange dimana kendala $\mathbf{a}_{\mathbf{2}}^{\prime} \mathbf{a}_{\mathbf{2}}=1$ dan $\mathbf{a}_{\mathbf{1}}^{\prime} \mathbf{a}_{\mathbf{2}}=1$ maka dengan operasi matematika diperoleh $\operatorname{Var}\left(Y_{2}\right)=\mathbf{a}_{\mathbf{2}}^{\prime} \sum \mathbf{a}_{\mathbf{2}}=\lambda_{2}$. Dengan demikian $\operatorname{Var}\left(Y_{2}\right)$ juga bernilai kedua terbesar jika $\lambda_{2}$ juga bernilai kedua terbesar.

Cara yang sama juga dilakukan dalam menentukan komponen utama ke tiga, ke empat hingga komponen utama ke- $p$. 


\subsubsection{Menentukan Banyaknya Komponen Utama}

Ada tiga metode yang umum digunakan untuk penentuan banyaknya komponen utama. Metode pertama didasarkan pada kumulatif proporsi keragaman total yang mampu dijelaskan oleh komponen-komponen utama. Metode kedua didasarkan pada ragam komponen utama yaitu nilai akar karakteristik. Metode ketiga adalah penggunaan grafik yang disebut plot scree.

\subsection{Analisis Gerombol Hibrid}

Analisis gerombol hibrid merupakan gabungan dari metode gerombol tak berhirarki dan berhirarki. Algoritma metode gerombol hibrid terdiri dari dua tahap yaitu:

Tahap pertama yaitu menggerombolkan objek-objek kedalam $k$ gerombol dengan menggunakan metode K-rataan. Nilai $k$ diduga sebesar $N^{(0.3)}$, dengan $N$ adalah jumlah objek/individu.

Tahap kedua yaitu menggerombolkan $k$ gerombol yang diperoleh pada tahap pertama dengan menggunakan gerombol berhirarki dan metode pautan tunggal (single Linkage) sebagai matriks perbaikan jarak. Pada tahap ini, matriks jarak untuk $k$ gerombol dibentuk berdasarkan definisi berikut.

Definisi 2.1. Dua gerombol $i$ dan $j$ dikatakan bertetangga jika $y_{i j}$ yaitu titik tengah antara $y_{i}$ dan $y_{j}$, lebih dekat ke $y_{i}$ atau ke $y_{j}$ dibanding ke gerombol lain.

Besarnya peluang dua gerombol $i$ dan $j$ untuk digabungkan dinyatakan dalam bentuk fungsi $f_{N}\left(y_{i j}\right)$ sebagai berikut :

$$
f_{N}\left(y_{i j}\right) \propto \frac{\left(n_{i}+n_{j}\right)^{1+\frac{p}{2}}}{\left(W S S_{i}+W S S_{j}+\frac{1}{4}\left(n_{i}+n_{j}\right) d^{2}\left(y_{i}, y_{j}\right)\right)^{\frac{p}{2}}}
$$

Definisi 2.2. Jarak antara dua gerombol $i$ dan $j$ adalah:

$$
d(i, j)= \begin{cases}\frac{1}{f_{N}\left(y_{i j}\right)} & \text { jika gerombol } i \text { dan } j \text { bertetangga } \\ \infty & \text { lainnya. }\end{cases}
$$

\section{Pembahasan}

\subsection{Gambaran Umum Data}

Pada paper ini akan dianalisis 41 perusahaan pada periode Juni 2016 dengan sepuluh komponen data keuangan. Berikut disajikan deskripsi data dari data komponen laporan keuangan tersebut berdasarkan masing-masing peubah:

Perusahaan-perusahaan yang memiliki karakteristik yang lebih baik berdasarkan nilai maksimum dan nilai minimum dari masing-masing komponen data keuangan pada periode tersebut adalah Astra International Tbk., Alam Sutera Realty Tbk., Bank Mandiri (Persero) Tbk., Indocement Tunggal Prakarsa Tbk., Matahari Department Store Tbk., Surya Citra Media Tbk., Telekomunikasi Indonesia (Persero) Tbk., dan Unilever Indonesia Tbk. 
Tabel 3.1.1. Gambaran Umum Data

\begin{tabular}{|c|c|c|c|c|c|c|}
\hline \multirow{3}{*}{ No } & \multirow{3}{*}{ Peubah } & Rata-Rata & $\begin{array}{c}\text { Simpangan } \\
\text { Baku }\end{array}$ & $\begin{array}{c}\text { Koefisien } \\
\text { Keragaman }\end{array}$ & $\begin{array}{c}\text { Nilai } \\
\text { Minimum } \\
\end{array}$ & $\begin{array}{c}\text { Nilai } \\
\text { Maksimum } \\
\end{array}$ \\
\hline & & Juni 2016 & Juni 2016 & Juni 2016 & Juni 2016 & Juni 2016 \\
\hline & & $\bar{x}_{2}$ & $S_{2}$ & $K K_{2}$ & $x_{2 \min }$ & $x_{2 \text { maks }}$ \\
\hline 1 & $\begin{array}{c}\text { Asset } \\
\text { (Jutaan } \\
\text { Rupiah) }\end{array}$ & 113.253 .827 .6 & $229,055,374.6$ & 2,02 & $\begin{array}{c}3.249 .598 \\
\text { (SILO) }\end{array}$ & $\begin{array}{c}971.444 .434 \\
\text { (BMRI) }\end{array}$ \\
\hline 2 & $\begin{array}{l}\text { Hutang } \\
\text { (Jutaan } \\
\text { Rupiah) }\end{array}$ & $81.451 .971,8$ & $189,860,951.0$ & 2,33 & $\begin{array}{l}1.151 .376 \\
\text { (SCMA) }\end{array}$ & $\begin{array}{c}774.179 .097 \\
\text { (BBRI) }\end{array}$ \\
\hline 3 & $\begin{array}{l}\text { Modal } \\
\text { (Jutaan } \\
\text { Rupiah) }\end{array}$ & $29.929 .420,1$ & $38,710,987.7$ & 1,29 & $\begin{array}{c}1.016 .431 \\
\text { (LPPF) }\end{array}$ & $\begin{array}{c}147.089 .194 \\
\text { (BMRI) }\end{array}$ \\
\hline 4 & $\begin{array}{c}\text { Pendapatan } \\
\text { (Jutaan } \\
\text { Rupiah) } \\
\end{array}$ & $14.592 .318,3$ & $17,655,523.2$ & 1,21 & $\begin{array}{l}494.532 \\
\text { (SSMS) }\end{array}$ & $\begin{array}{l}88.208 .000 \\
\text { (ASII) }\end{array}$ \\
\hline 5 & $\begin{array}{l}\text { Laba } \\
\text { (Jutaan } \\
\text { Rupiah) }\end{array}$ & $2.288 .745,2$ & $3,361,555.6$ & 1,47 & $\begin{array}{l}-264.167 \\
\text { (INCO) }\end{array}$ & $\begin{array}{c}14.663 .000 \\
(\mathrm{TLKM})\end{array}$ \\
\hline 6 & DAR & 0,5259 & 0.2069 & 0,39 & $\begin{array}{c}0,11 \\
\text { (INTP) }\end{array}$ & $\begin{array}{c}0,91 \\
(\mathrm{BBTN})\end{array}$ \\
\hline 7 & DER & 1,833 & 1.983 & 1,08 & $\begin{array}{c}0,12 \\
\text { (INTP) }\end{array}$ & $\begin{array}{c}9,8 \\
(\mathrm{BBTN})\end{array}$ \\
\hline 8 & ROA (\%) & 4,283 & 4.791 & 1,12 & $\begin{array}{c}-0,90 \\
\text { (INCO) }\end{array}$ & $\begin{array}{c}21,88 \\
(\mathrm{LPPF}) \\
\end{array}$ \\
\hline 9 & ROE (\%) & 10,99 & 19.44 & 1,77 & $\begin{array}{c}-1,10 \\
(\mathrm{INCO})\end{array}$ & $\begin{array}{l}113,84 \\
\text { (LPPF) }\end{array}$ \\
\hline 10 & NPM (\%) & 15,73 & 11.87 & 0,75 & $\begin{array}{c}-8,12 \\
\text { (INCO) }\end{array}$ & $\begin{array}{c}43,54 \\
\text { (ASRI) }\end{array}$ \\
\hline
\end{tabular}

\subsection{Analisis Gerombol Hibrid}

\subsubsection{Gerombol Tak Berhirarki (K-Rataan)}

Pada tahap pertama, dilakukan penggerombolan dengan menggunaka algoritma K-Rataan MacQueen. Pada tahap ini jumlah gerombol ditentukan sebanyak tiga gerombol, yang diperoleh dari : $K=N^{0,3}=41^{0,3}=3,05 \equiv 3$.

Hasil penggerombolan tahap pertama dapat dilihat pada Tabel 3.2.1.

\subsubsection{Gerombol Berhirarki}

Pada tahap kedua dilakukan penggerombolan dengan analisis gerombol berhirarki penggabungan dengan metode perbaikan jarak menggunakan metode pautan tunggal. Pada tahap ini, gerombol-gerombol hasil tahap pertama (K-Rataan) yang mempunyai nilai $d(i, j)$ terkecil akan digabungkan kembali menjadi satu gerombol. Sebelum melakukan penggabungan gerombol, dihitung terlebih dahulu besar peluang dua gerombol i dan j dapat digabungkan berdasarkan Definisi 2.4.1. Lalu dicari jarak antara dua gerombol i dan j tersebut sesuai Definisi 2.4.2. Hasil dari matriks jarak dapat ditampilkan dalam bentuk dendogram yang disajikan pada Gambar 3.2.1.

Selisih jarak terbesar terjadi antara jarak penggabungan gerombol (I,II) dengan gerombol III. Anggota gerombol I pada penggerombolan tahap kedua merupakan gabungan dari anggota gerombol I, II pada penggerombolan tahap pertama, sedangkan anggota dari gerombol II pada penggerombolan tahap kedua merupakan anggota dari gerombol III pada tahap pertama. Distribusi perusahaan masing- 
Tabel 3.2.1 Distribusi Perusahaan Hasil Penggerombolan Tahap Pertama

\begin{tabular}{|c|c|c|c|}
\hline Ger & Frek & \multicolumn{2}{|c|}{ Nama Perusahaan } \\
\hline I & 26 & $\begin{array}{l}\text { 1. Astra Agro Lestari Tbk. } \\
\text { 2. Adaro Energy Tbk. } \\
\text { 3. AKR Corporindo Tbk. } \\
\text { 4. Alam Sutera Realty Tbk. } \\
\text { 5. Global Mediacom Tbk. } \\
\text { 6. Bumi Serpong Damai Tbk. } \\
\text { 7. Charoen Pokphand Indonesia Tbk. } \\
\text { 8. Gudang Garam Tbk. } \\
\text { 9. Indofood CBP Sukses Makmur Tbk. } \\
\text { 10. Vale Indonesia Tbk. } \\
\text { 11. Indofood Sukses Makmur Tbk. } \\
\text { 12. Indocement Tunggal Prakasa Tbk. } \\
\text { 13. Kalbe Farma Tbk. } \\
\text { 14. Lippo Karawaci Tbk. }\end{array}$ & $\begin{array}{l}\text { 15. Matahari Department Store Tbk. } \\
\text { 16. PP London Sumatera Tbk. } \\
\text { 17. Media Nusantara Citra Tbk. } \\
\text { 18. Perusahaan Gas Negara (Persero) Tbk. } \\
\text { 19. Tambang Batubara Bukit Asam } \\
\text { (Persero) Tbk. } \\
\text { 20. Pakuwon Jati Tbk. } \\
\text { 21. Surya CitranMedia Tbk. } \\
\text { 22. Silom International Hospitals Tbk. } \\
\text { 23. Semen Indonesia (Persero) Tbk. } \\
\text { 24. Sawit Subermas Sarana Tbk. } \\
\text { 25. United Tractors Tbk. } \\
\text { 26. Unilever Indonesia Tbk. }\end{array}$ \\
\hline II & 9 & $\begin{array}{l}\text { 1. Adhi Karya (Persero) Tbk. } \\
\text { 2. Bank Tabungan Negara (Persero) } \\
\text { Tbk. } \\
\text { 3. Jasa Marga (Persero) Tbk. } \\
\text { 4. Matahari Putra Prima Tbk. }\end{array}$ & $\begin{array}{l}\text { 5. PP (Persero) Tbk. } \\
\text { 6. Summarecon Agung Tbk. } \\
\text { 7. Sri Rejeki Isman Tbk. } \\
\text { 8. Wijaya Karya (Persero) Tbk. } \\
\text { 9. Waskita Karya (Persero) Tbk. }\end{array}$ \\
\hline III & 6 & $\begin{array}{l}\text { 1. Astra International Tbk. } \\
\text { 2. Bank Central Asia Tbk. } \\
\text { 3. Bank Negara Indonesia (Persero) } \\
\text { Tbk. }\end{array}$ & $\begin{array}{l}\text { 4. Bank Rakyat Indonesia (Persero) Tbk. } \\
\text { 5. Bank Mandiri (persero) Tbk. } \\
\text { 6. Telekomunikasi Indonesia (Persero) } \\
\text { Tbk. }\end{array}$ \\
\hline $10 t a 1$ & 41 & & \\
\hline
\end{tabular}

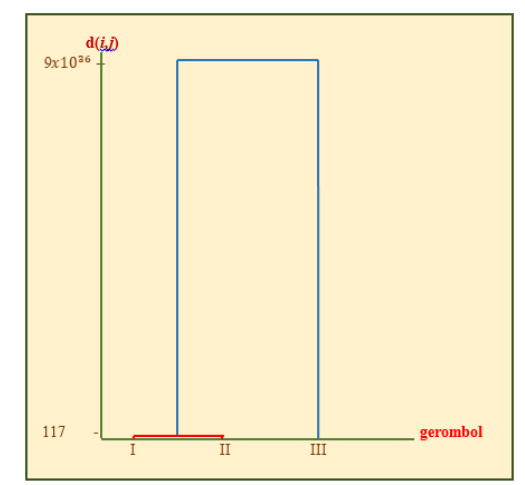

Gambar 3.2.1 Dendogram Hasil Penggerombolan Tahap Kedua

masing gerombol tahap kedua dapat dilihat pada Tabel 3.2.2.

Kategori nilai rata-rata skor komponen utama untuk masing-masing gerombol, yang menunjukkan ciri-ciri dari masing-masing gerombol dilihat dari rata-rata skor komponen utama. Pengkategorian tersebut dapat dilihat pada Tabel. 3.2.3.

Dari Tabel 3.2.3 tersebut, dapat dilihat bahwa perusahaan-perusahaan pada gerombol II dicirikan oleh asset, modal, pendapatan dan laba yang relatif tinggi, namun juga memiliki hutang yang juga relatif tinggi dibanding perusahaanperusahaan pada gerombol I. Sedangkan perusahaan-perusahaan pada gerombol I adalah perusahaan dengan nilai komponen data keuangan yang relatif sedang. Dengan demikian, berdasarkan peubah asset, modal, pendapatan, dan laba maka bisa dikatakan bahwa secara umum gerombol II memiliki komponen data keuangan 
14 Penggerombolan Perusahaan dengan Analisis Gerombol Hibrid

Tabel 3.2.2 Distribusi Perusahaan Hasil Penggerombolan Tahap Kedua

\begin{tabular}{|c|c|c|c|}
\hline Ger & Frek & \multicolumn{2}{|c|}{ Nama Perusahaan } \\
\hline I & 35 & \begin{tabular}{|l|} 
1. \\
2. Astra Agro Lestari Tbk. \\
3. Adaro Energy Tbk. \\
4. AKR Corporindo Tbk. \\
5. Alam Sutera Realty Tbk. \\
6. Bank Tabungan Negara (Persero) \\
Tbk. \\
7. Global Mediacom Tbk. \\
8. Bumi Serpong Damai Tbk. \\
9. Charoen Pokphand Indonesia Tbk \\
10. Gudang Garam Tbk. \\
11. Indofood CBP Sukses Makmur \\
Tbk. \\
12. Vale Indonesia Tbk. \\
13. Indofood Sukses Makmur Tbk. \\
14. Indocement Tunggal Prakasa Tbk. \\
15. Jasa Marga (Persero) Tbk. \\
16. Kalbe Farma Tbk. \\
17. Lippo Karawaci Tbk
\end{tabular} & $\begin{array}{l}\text { 18. Matahari Department Store Tbk. } \\
\text { 19. PP (Persero) Tbk. } \\
\text { 20. PP London Sumatera Tbk. } \\
\text { 21. Media Nusantara Citra Tbk. } \\
\text { 22. Matahari Putra Prima Tbk. } \\
\text { 23. Perusahaan Gas Negara (Persero) Tbk. } \\
\text { 24. Tambang Batubara Bukit Asam } \\
\text { (Persero) Tbk. } \\
\text { 25. Pakuwon Jati Tbk. } \\
\text { 26. Surya Citra Media Tbk. } \\
\text { 27. Silom International Hospitals Tbk. } \\
\text { 28. Semen Indonesia (Persero) Tbk. } \\
\text { 29. Summarecon Agung Tbk. } \\
\text { 30. Sri Rejeki Isman Tbk } \\
\text { 31. Sawit Subermas Sarana Tbk. } \\
\text { 32. United Tractors Tbk. } \\
\text { 33. Unilever Indonesia.Tbk. } \\
\text { 34. Wijaya Karya (Persero) Tbk. } \\
\text { 35. Waskita Karya (Persero) Tbk. } \\
\end{array}$ \\
\hline II & 6 & $\begin{array}{l}\text { 1. Astra International Tbk. } \\
\text { 2. Bank Central Asia Tbk. } \\
\text { 3. Bank Negara Indonesia (Persero) } \\
\text { Tbk. }\end{array}$ & $\begin{array}{l}\text { 4. Bank Rakyat Indonesia (Persero) Tbk. } \\
\text { 5. Bank Mandiri (persero) Tbk. } \\
\text { 6. Telekomunikasi Indonesia (Persero) } \\
\text { Tbk. }\end{array}$ \\
\hline Total & 41 & & \\
\hline
\end{tabular}

Tabel 3.2.3 Kategori Rata-rata Skor Komponen Utama untuk Setiap Gerombol

\begin{tabular}{|c|r|r|}
\hline Gerombol & \multicolumn{1}{|c|}{ I } & \multicolumn{1}{|c|}{ II } \\
\hline Asset (Jutaan Rupiah) & $33.652 .538(\mathrm{~s})$ & $577.594 .682(\mathrm{t})$ \\
\hline Hutang (Jutaan Rupiah) & $18.371 .002(\mathrm{~s})$ & $449.424 .297(\mathrm{t})$ \\
\hline Modal (Jutaan Rupiah) & $15.281 .537(\mathrm{~s})$ & $115.375 .407(\mathrm{t})$ \\
\hline Pendapatan (Jutaan Rupiah) & $9.291 .192(\mathrm{~s})$ & $45.515 .556(\mathrm{t})$ \\
\hline Laba (Jutaan Rupiah) & $1.062 .556(\mathrm{~s})$ & $9.441 .514(\mathrm{t})$ \\
\hline DAR & $0,4957(\mathrm{~s})$ & $0,7017(\mathrm{~s})$ \\
\hline DER & $1,489(\mathrm{~s})$ & $3,837(\mathrm{t})$ \\
\hline ROA (\%) & $4,550(\mathrm{~s})$ & $2,723(\mathrm{~s})$ \\
\hline ROE (\%) & $11,43(\mathrm{~s})$ & $8,44(\mathrm{~s})$ \\
\hline NPM $(\%)$ & $14,36(\mathrm{~s})$ & $23,70(\mathrm{~s})$ \\
\hline
\end{tabular}

Ket $; \mathrm{r}=$ rendah, $\mathrm{s}=$ sedang, $\mathrm{t}=$ tinggi

yang lebih unggul dibandingkan dengan ciri komponen data keuangan gerombol I.

\section{Penutup}

Pada paper ini dilakukan penggerombolan 41 perusahaan yang tergabung dalam kelompok perusahaan LQ45 berdasarkan komponen data keuangan pada periode Juni 2016. Berdasarkan analisis, 41 perusahaan tersebut dikelompokkan menjadi dua gerombol,yang mana gerombol I terdiri atas 35 perusahaan dengan ciri komponen data keuangan yang relatif sedang dan gerombol II terdiri atas enam perusahaan dengan ciri komponen data keuangan yang relatif tinggi. Berdasarkan ciri komponen data keuangan tersebut, maka bisa dikatakan secara umum perusahaan-perusahaan 
pada gerombol II lebih unggul dibandingkan perusahaan pada gerombol I.

\section{Ucapan Terima Kasih}

Penulis mengucapkan terima kasih kepada Ibu Dr. Ferra Yanuar, Bapak Dr. Dodi Devianto, Bapak Yudiantri Asdi, M.Sc yang telah memberikan masukan dan saran sehingga paper ini dapat diselesaikan dengan baik.

\section{Daftar Pustaka}

[1] Hery. 2016. Analisis Laporan Keuangan. PT Grasindo, Jakarta

[2] Johnso, R.A dan D.W. Wichern. 1998. Applied Multivariate Statistical Analyisis.. Fourth Edition. Prentice-Hall International, Inc, London

[3] Jollife, I.T. 1986. Principle Component Analyisis. Springer-Verlag, New York

[4] Wong, M.A. 1982. A Hybrid Clustering Method for Identifying High Density Cluster. JASA $77: 841-847$ 